\title{
Study of the Simple Multi-Attribute Rating Technique For Decision Support
}

\author{
Risawandi $^{1}$, Robbi Rahim ${ }^{2 *}$ \\ ${ }^{1}$ University of Malikussaleh, Jl.Cot Teungku Nie-Reulet, North Aceh, Aceh, Indonesia \\ ${ }^{2}$ Departement of Computer Engineering, Medan Institute of Technology, Jalan Gedung Arca No.52, Medan, \\ Indonesia
}

\begin{abstract}
Making a decision is a crucial step in a management, the decision will have a significant impact on the policies to be taken by the top management, SMART (Simple Multi-Attribute Rating Technique) is the method used for making a decision with the completion of many criteria with results pretty good, this study provides an overview of how the methods SMART (Simple Multi-Attribute Rating Technique) works with many criteria.
\end{abstract}

Keywords : DSS, Decision Support System, SMART Method, SMART Algorithm, SMART, Multi-Attribute

\section{INTRODUCTION}

Decision support system is part of a computer-based information system (including a knowledge-based system or knowledge management) that is used to support decision making in an organization or company [1] [2].

Decision support system has several methods that can apply to a method Weight Product (WP), Simple Addictive Weighting (SAW), Analytics Hierarchy Process (AHP) and some other methods [3]. However, of these types of methods of decision support systems that exist, the simplest method to respond to the immediate needs of decision makers is a method Simple Multi-Attribute Rating Technique (SMART) [1] [2] [4]. SMART method is a method of decision support system that applied by giving weight values for each criterion that illustrates how important these criteria other than the criteria [3] [5] [6].

\section{METHODS AND MATERIAL}

\section{Decision Support System}

Decision support system is an information system that is intended to assist management in the decision-making process. Decision support system combines the capabilities of a computer in interactive services with the processing or manipulation of data or models that utilize unstructured settlement rules [3] [7].

\section{Simple Multi Attribute Rating Technique (SMART)}

Simple Multi Attribute Rating (SMART) is a comprehensive model of decision-makers to account for things that are qualitative and quantitative. In a decisionmaking model with SMART trying to cover any shortfall from the previous model without computerization [6] [8]. SMART is also possible to structure a system and environment into components interact with each other and then unite them with measure and regulate the effects of the elements of a system error [8].

The main equipment of this model is a functional hierarchy with main input is human perception [3] [5]. So basically there is no significant difference in the SMART model with other models at the same lies in the type of input, it is just that there is a percentage of each linear weighting determined by the results of analysis of the problem [5].

SMART weighting method is a method of supporting the simplest decision [2]. In this method seen some parameter that determines the decision. These 
parameters have a range of values and weights vary. The value will be the determinant of the decision taken [9].

The weighting of SMART (Simple Multi-Attribute Rating Technique) using a scale between 0 and 1 , thus simplifying the calculation and comparison of the value of each alternative [9][10]. The model applied in the SMART (Simple Multi-Attribute Rating Technique) are:

$$
u\left(a_{i}\right)=\sum_{j=1}^{m} w_{j} u_{i}\left(a_{i}\right), i=1,2,,,, m
$$

The following is the order in which the SMART method based on the above functions

1. Determine the number of criteria used.

2. Determine the criteria weights to each criterion by using the 1-100 interval for each criterion with the most urgent priority.

3. Calculate the normalization of each of the criteria by comparing the weights of criteria by the number of weighted criteria. Using the formula

the normalization

$$
=\frac{w_{j}}{\sum_{w_{j}}}
$$

Where ${ }^{w_{j}}$ is the weight value of criteria? While $\Sigma_{w_{j}}$ is the total weight of all criteria

4. Provide criteria parameter value on each criterion for each alternative.

5. Determine the value of the utility to convert the value of the criteria for each criterion into the value of the raw data criteria. Utility value is obtained using the equation:

$$
u_{i}\left(a_{i}\right)=\frac{c_{\text {out }-c_{\min }}}{c_{\max }-c_{\min }}
$$

Where $u_{i}\left(a_{i}\right)$ is the utility value of the criteria to-1 for the criteria to - I, $c_{\max }$ is the maximum value criteria, $c_{\min }$ is the value of the minimum criteria and $c_{\text {out }} i$ is a value criterion to - I. The importance of these values are:

$$
c_{\text {out }} i=u_{i}\left(a_{i}\right), 1=0 ; 2=0.5 ; 3=1
$$

6. Determine the final value of each criterion by shifting the values obtained from the normalized value of the raw data criteria with weight normalized value criteria. Then total value of the multiplication like function (1).

\section{RESULTS AND DISCUSSION}

Analysis of the determination of the criteria is a study conducted to determine the criteria to be used to take a decision, for example, SMART method of analysis is the identification of the following criteria:

TABLE I . Criteria

\begin{tabular}{|l|l|}
\hline No. & Criteria $(\mathrm{C})$ \\
\hline 1. & $\mathrm{C} 1$ \\
\hline 2. & $\mathrm{C} 2$ \\
\hline 3. & $\mathrm{C} 3$ \\
\hline 4. & $\mathrm{C} 4$ \\
\hline
\end{tabular}

Decision-making techniques using the SMART method based on the theory that each alternative consists of some criteria that have values and each of the criteria has a weight that illustrates how important compared with other criteria. Completion of the SMART method were done in steps such as:

\section{Determining Alternative}

The first stage in making a decision using the SMART method are first to determine alternatives used as

\begin{tabular}{|c|c|c|c|c|}
\hline \multirow{2}{*}{$\begin{array}{l}\text { Alterna } \\
\text { tive }\end{array}$} & \multicolumn{4}{|c|}{ Criteria (C) } \\
\hline & $\begin{array}{l}\text { Stock } \\
\text { (C1) }\end{array}$ & $\begin{array}{l}\text { Price } \\
(\mathrm{C} 2)\end{array}$ & $\begin{array}{l}\text { Quality } \\
\text { (C3) }\end{array}$ & $\begin{array}{l}\text { Size } \\
\text { (C4) }\end{array}$ \\
\hline A1 & $\pm 600 \mathrm{Kg}$ & Rp. 49500 & Enough & Mid \\
\hline A2 & $\pm 800 \mathrm{Kg}$ & Rp. 67500 & Enough & Mid \\
\hline A3 & $\pm 400 \mathrm{Kg}$ & RP. 11000 & $\begin{array}{l}\text { Not } \\
\text { Good }\end{array}$ & Large \\
\hline A4 & $\pm 600 \mathrm{~kg}$ & Rp. 18500 & Good & $\begin{array}{l}\text { Very } \\
\text { Large }\end{array}$ \\
\hline
\end{tabular}
experimental. The alternative was used as the experiment can be seen in the following table.

TABLE II. Altenative 
2. Value weighting of criteria determined by the greatest weight to the weight of the smallest to the interval 0-100 and used as default values in the system. Then all values are summed.

TABLE III. Weight of Criteria

\begin{tabular}{|l|l|l|}
\hline No. & Criteria $(\mathrm{C})$ & $\begin{array}{l}\text { Weight } \\
(\mathrm{Wj})\end{array}$ \\
\hline 1. & $\mathrm{C} 1$ & 50 \\
\hline 2. & $\mathrm{C} 2$ & 30 \\
\hline 3. & $\mathrm{C} 3$ & 10 \\
\hline 4. & $\mathrm{C} 4$ & 10 \\
\hline \multicolumn{2}{|l|}{ Sum } & 100 \\
\hline
\end{tabular}

3. Weight value predetermined criteria of the largest of the highest to the lowest is not important which will be normalized by dividing the weight of criteria weights (wj) with a total weight value $\left(\sum w j\right)$. The normalization weighting criteria may describe in the following table

TABLE IV. Weight of the normalization Criteria

\begin{tabular}{|l|l|l|l|}
\hline No & $\begin{array}{l}\text { Criteria } \\
(\mathrm{C})\end{array}$ & $\begin{array}{l}\text { Weight } \\
(\mathrm{Wj})\end{array}$ & $\begin{array}{l}\text { Normalisasi } \\
\left(\frac{w j}{\sum w j}\right)\end{array}$ \\
\hline 1. & $\mathrm{C} 1$ & 50 & $50 / 100=0,5$ \\
\hline 2. & $\mathrm{C} 2$ & 30 & $30 / 100=0,3$ \\
\hline 3. & $\mathrm{C} 3$ & 10 & $10 / 100=0,1$ \\
\hline 4. & $\mathrm{C} 4$ & 10 & $10 / 100=0,1$ \\
\hline
\end{tabular}

The next stage in the completion of the SMART method is to give the parameter value criteria. The parameter values will be grouped as follows.

TABLE V. Parameter Values

\begin{tabular}{|l|l|}
\hline Group & $\begin{array}{l}\text { Parameter } \\
\text { Value }\end{array}$ \\
\hline Low & 1 \\
\hline Mid & 2 \\
\hline High & 3 \\
\hline Very High & 4 \\
\hline
\end{tabular}

Explanation of the above table can conclude about the classification criteria used. Grouping the criteria described in the following table

TABLE VI. Value of Sub Criteria

\begin{tabular}{|c|c|c|c|}
\hline No. & $\begin{array}{l}\text { Criteria } \\
\text { (C) }\end{array}$ & Stock & Value \\
\hline 1. & $\mathrm{C} 1$ & $\begin{array}{l}\text { 1. }>600 \mathrm{Kg} \\
\text { 2. } 400 \mathrm{~kg}-600 \mathrm{~kg} \\
\text { 3. } 200 \mathrm{~kg}-399 \mathrm{~kg} \\
\text { 4. }<200 \mathrm{~kg}\end{array}$ & $\begin{array}{l}4 \\
3 \\
2 \\
1\end{array}$ \\
\hline 2. & $\mathrm{C} 2$ & $\begin{array}{l}\text { 1. }>50000 \\
\text { 2. } 30000-50000 \\
\text { 3. } 10000-29000 \\
\text { 4. }<10000\end{array}$ & $\begin{array}{l}4 \\
3 \\
2 \\
1\end{array}$ \\
\hline 3. & C3 & $\begin{array}{l}\text { 1. Very Good } \\
\text { 2. Good } \\
\text { 3. Enough } \\
\text { 4. Low }\end{array}$ & $\begin{array}{l}4 \\
3 \\
2 \\
1\end{array}$ \\
\hline 4. & C4 & $\begin{array}{l}\text { 1. Very Large } \\
\text { 2. Large } \\
\text { 3. Mid } \\
\text { 4. Low }\end{array}$ & $\begin{array}{l}3 \\
2 \\
1 \\
4\end{array}$ \\
\hline
\end{tabular}

The above table describes the classification criteria and value. From the table, it can be given to each of the criteria value of alternative use. The value of these criteria is described in the following table.

TABLE VII. Value of Sub Criteria For Alternatives

\begin{tabular}{|l|l|l|l|l|}
\hline $\begin{array}{l}\text { Criterial } \\
\text { Alternative }\end{array}$ & C1 & C2 & C3 & C4 \\
\hline A1 & 3 & 3 & 2 & 1 \\
\hline A2 & 4 & 4 & 2 & 1 \\
\hline A3 & 3 & 2 & 1 & 2 \\
\hline A4 & 3 & 2 & 4 & 3 \\
\hline
\end{tabular}

The above table describes the rating criteria of each alternative then the value will be converted to seek his utility value.

Determining the value of the utility to convert the value of the criteria to - one of the criteria to - I using the 
equation $u i(a i)=\frac{C_{\text {outi }-C_{\min }}}{C_{\max }-C_{\min }}$ Then the results of the calculation are:

1. If the value criteria $\left(C_{\text {Out }}\right)=4$, then $u i(a i)=\frac{4-1}{4-1}=1$

2. If the value criteria $\left(C_{\text {Out }}\right)=3$, then $u i(a i)=\frac{3-1}{4-1}=$ 0,66666667

3. If the value criteria $\left(C_{\text {Out }}\right)=2$, then $u i(a i)=\frac{2-1}{4-1}=$ 0,33333333

4. If the value criteria $\left(C_{\text {Out }}\right)=1$, then $u i(a i)=\frac{1-1}{4-1}=0$

The following stage is the calculation of the final value of each alternative by multiplying the utility value criteria with normalized weight value corresponding formula $u(a i)=\sum_{j=i}^{m} w j u i(a i)$, The results of the calculation of the final value will be adjusted to a range of considerations. The description is as follows

TABLE VIII. Final Score

\begin{tabular}{|c|c|c|c|c|c|}
\hline No. & $\begin{array}{l}\text { Alternativ } \\
\text { e } \\
\text { (A) }\end{array}$ & $\begin{array}{l}\text { Criteri } \\
\mathrm{a} \\
\text { (C) }\end{array}$ & $\begin{array}{l}\text { Value } \\
\text { Utilities }\end{array}$ & $\begin{array}{l}\text { Weigh } \\
t \\
\text { of } \\
\text { normal } \\
\text { ization }\end{array}$ & $\begin{array}{l}\text { Scor } \\
\mathrm{e}\end{array}$ \\
\hline 1. & A1 & $\begin{array}{l}\mathrm{C} 1 \\
\mathrm{C} 2 \\
\mathrm{C} 3 \\
\mathrm{C} 4\end{array}$ & $\begin{array}{l}0,66 \\
0,66 \\
0,33 \\
0\end{array}$ & $\begin{array}{l}0,5 \\
0,3 \\
0,1 \\
0,1\end{array}$ & 0,56 \\
\hline 2. & A2 & $\begin{array}{l}\mathrm{C} 1 \\
\mathrm{C} 2 \\
\mathrm{C} 3 \\
\mathrm{C} 4\end{array}$ & $\begin{array}{l}1 \\
1 \\
0,33 \\
0\end{array}$ & $\begin{array}{l}0,5 \\
0,3 \\
0,1 \\
0,1\end{array}$ & 0,83 \\
\hline 3. & A3 & $\begin{array}{l}\mathrm{C} 1 \\
\mathrm{C} 2 \\
\mathrm{C} 3 \\
\mathrm{C} 4\end{array}$ & $\begin{array}{l}0,66 \\
0,33 \\
0 \\
0,33\end{array}$ & $\begin{array}{l}0,5 \\
0,3 \\
0,1 \\
0,1\end{array}$ & 0,46 \\
\hline 4. & A4 & $\begin{array}{l}\mathrm{C} 1 \\
\mathrm{C} 2 \\
\mathrm{C} 3 \\
\mathrm{C} 4\end{array}$ & $\begin{array}{l}0,66 \\
0,33 \\
1 \\
0,66\end{array}$ & $\begin{array}{l}0,5 \\
0,3 \\
0,1 \\
0,1\end{array}$ & 0,6 \\
\hline
\end{tabular}

The calculation of the final value that has done obtained the highest score based on the rank order are A2 with a value of 0,83 and can be recommended by SMART algorithm.

\section{CONCLUSION}

This study provides little process regarding the use of the SMART method as the decision-making process with many criteria, the results of decision-making based on the example described earlier are only a small example only, and SMART method can be developed further by combining it with other methods or add specific functionality.

\section{REFERENCES}

[1]. Arh, T., \& Blaži, B. J. (2007). Application of MultiAttribute Decision Making Approach to Learning Management Systems Evaluation . JOURNAL OF COMPUTERS, 2(10), 28-37.

[2]. BÂRA, A., BOTHA, I., LUNGU, I., \& OPREA, S. V. (2013). Decision Support System in National Power Companies A Practical Example (Part I) . Database Systems Journal, IV(1), 37-45.

[3]. Conejar, R. J., \& Hon Kim, H. (2014). A Medical Decision Support System (DSS) for Ubiquitous Healthcare Diagnosis System. International Journal of Software Engineering and Its Applications, 8(10), 237-244.

[4]. Goodwin, P. (2003). Decision Analysis for Management Judgment, 3rd Edition. US: Wiley.

[5]. Kasie, F. M. (2013). Combining Simple Multiple Attribute Rating Technique and Analytical Hierarchy Process for Designing Multi-Criteria Performance Measurement Framework. Global Journal of Researches in Engineering Industrial Engineering, 13(1), 15-30.

[6]. Kuhn, M. (2002). Introduction to Decision Support Software. Berlin: Adelphi Research.

[7]. MOHEMAD, R., HAMDAN, A., OTHMAN, Z., \& MOHAMAD NOOR, N. (2010). Decision Support Systems (DSS) in Construction Tendering Processes . International Journal of Computer Science, 7(2), 35-45.

[8]. Mustajoki, J., \& Hämäläinen, R. (2007). SmartSwaps - A decision support system for multicriteria decision analysis with the even swaps method. Science Direct, 44(1), 313-325.

[9]. Taylor Jr, J., \& Love, B. (2014). Simple MultiAttribute Rating Technique for Renewable Energy Deployment Decisions(SMART REDD). Journal of Defense Modeling and Simulation: Applications, Methodology, Technology, 11(3), 227-232.

[10]. Turban, E., Aronson, J., \& Liang, T.-P. (2005). Decision Support System and Intelligent System. US: Prentice-Hall. 